
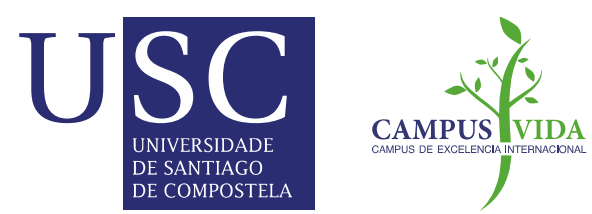

\title{
Energetic and economic assessment of sludge thermal hydrolysis in novel wastewater treatment plant configurations
}

Anton Taboada-Santos, Juan M. Lema and Marta Carballa

\section{Accepted Manuscript}

\section{How to cite:}

Taboada-Santos, A., Lema, J., \& Carballa, M. (2019). Energetic and economic assessment of sludge thermal hydrolysis in novel wastewater treatment plant configurations Waste Management, 92 3038. doi: https://doi.org/10.1016/j.wasman.2019.05.003

\section{Copyright information:}

(C) Elsevier 2019 
1 Energetic and economic assessment of sludge thermal hydrolysis in

\section{2 novel wastewater treatment plant configurations}

3 Anton Taboada-Santos*, Juan M. Lema and Marta Carballa

4 Department of Chemical Engineering, School of Engineering, Universidade de Santiago

5 de Compostela, E- 15782, Santiago de Compostela, Spain.

6 *Anton Taboada-Santos: corresponding author

7 E-mail: anton.taboada@usc.es

8 Tel: +34 881816021 ; Fax: +34 881816702

9

10 E-mail addresses: anton.taboada@usc.es (A. Taboada-Santos), juan.lema@usc.es (J.M.

11 Lema),_marta.carballa@usc.es (M. Carballa). 
Abstract

Novel wastewater treatment plants (WWTPs) are aimed to be more energetically

efficient than conventional ones. Their first step is a chemical oxygen demand (COD) preconcentration stage with different alternatives, such as rotating belt filters (RBF), chemically enhanced primary treatment (CEPT), high-rate activated sludge (HRAS), or combinations thereof, in which energy requirements are substantially reduced. The COD recovered as sludge allows a noticeable increase of biogas production in anaerobic digestion (AD). In conventional WWTPs, sludge anaerobic biodegradability can be significantly enhanced by applying sludge pretreatment methods, such as thermal hydrolysis (TH), before AD. However, considering that novel-sludges are more anaerobically biodegradable than conventional ones, the impact of $\mathrm{TH}$ on their methane production is expected to result significantly lower. In this study, an energetic and economic assessment of applying TH in novel WWTPs was performed. We found that $\mathrm{TH}$ is only justified to reduce operational costs as long as sludge TS concentration in the feeding to the TH unit is higher than $1-2 \%$. The HRAS is the scenario that leads to the lowest treatment costs (below $1 \mathrm{c} € / \mathrm{m}^{3}$ wastewater if sludge is thickened over $10 \%$ of TS). However, the WWTP based on CEPT for COD preconcentration leads to the lowest electricity consumption (below $0.01 \mathrm{kWh} / \mathrm{m}^{3}$ of wastewater), but even in the most favourable conditions the energy autarky was not achievable. Results show that the main impact of TH is mainly due to sludge disposal savings (270,000-430,000 $€ /$ year for a 500,000 inhabitants WWTP) rather than the increase of energy production (achieves maximum savings of 35,000-60,000 €/year). Payback time is very dependent on the WWTP size, ranging from 15 to 30 years for a 100,000 inhabitants WWTP and from 2 to 4 years for a 1,000,000 inhabitants WWTP. 
36 Keywords: anaerobic digestion, economy of scale, energy autarky, high-rate activated 37 sludge, payback time, sludge disposal. 


\section{Introduction}

Traditional wastewater treatment plants (WWTPs) have traditionally applied the conventional nitrification-denitrification process, which consumes high amounts of electrical energy and chemical oxygen demand (COD) for aeration and conversion of nitrate to nitrogen, respectively (Siegrist et al., 2008). They are electrical consumers with an usual demand in the range of 0.3 to $0.6 \mathrm{kWh} / \mathrm{m}^{3}$ wastewater treated (Gikas, 2018). 
European Directive 86/278/CEE promotes the use of sewage sludge in agriculture and up to 4-4.5 million ton of TS of sewage sludge were used in Europe in years 2010-2012 as a fertilizer (http://epp. eurostat.ec.europa.eu). Although this Directive does not consider the presence of pathogens, there is an agreement between policy makers, scientists and population that thresholds should be implemented. For this reason, the European Commission developed the 3rd draft working document on sludge (EC, 2000), that was not finally implemented mainly to the associated costs to the proposed more restrictive thresholds. The European Commission (EC, 2008) evaluated these limits in order to implement a more restrictive legislation, but the lack of consensus among the Member States of the European Commission made that the Directive 86/278/CEE could not be modified, confirming that it is not easy to establish more strict limits at European level. However,11 out of 27 EU countries have adopted more restrictive legislation (Kacprzak et al., 2017; Kelessidis and Stasinakis, 2012), establishing thresholds for pathogens not achievable during mesophilic AD (Astals et al., 2012). Therefore, mesophilic digested sludge usually needs further treatment before its agricultural use, this representing up to $50 \%$ of the WWTP costs (Vázquez-Padín et al., 2011), which can be avoided when TH is included before AD.

The methane production increase is a second advantage. There is a consensus in the literature that, whereas biomethane potential (BMP) of primary sludge is barely affected by TH $(<20 \%)$, BMP of waste activated sludge (WAS) can be increased up to $76 \%$ (Bougrier et al., 2006a, 2006b; Carrère et al., 2010; Fdz-Polanco et al., 2008; PerezElvira et al., 2008). However, considering the noticeable higher BMP for sludges from RBF, CEPT and HRAS in comparison with traditional ones (Ge et al., 2017; Ju et al., 2016; Paulsrud et al., 2014), the impact of TH on increasing methane yield is expected to be lower. 
The goal of this work is to study how the energetic and economic balance in a novel WWTP can be affected by the installation of a thermal hydrolysis unit.

\section{Materials and methods}

In this section the materials and methods used to generate the data needed to perform the energetic and economic assessment are presented.

\subsection{Wastewater treatment and sludge production}

RBF sludge was taken from a RBF placed in Blaricum WWTP (The Netherlands), with a typical mesh size of $350 \mu \mathrm{m}$ (Behera et al., 2018) treating around 1,600 $\mathrm{m}^{3} / \mathrm{h}$ of wastewater. CEPT sludge was generated in a pilot plant located in a WWTP in the north-west of Spain. The pilot plant, described by Suarez et al. (2009), was fed with 100 $\mathrm{L} / \mathrm{h}$ of wastewater and operated at a hydraulic retention time (HRT) of 30 minutes with the addition of $125-150 \mathrm{mg} / \mathrm{L}$ of ferric chloride. Two types of HRAS sludge were considered: HRAS I, from a WWTP in the centre of Spain, which treats an average flow of 2,200 $\mathrm{m}^{3} / \mathrm{h}$ of wastewater. The plant consists on a heterotrophic HRAS reactor working with a HRT of 6-7 hours and a solid retention time (SRT) of 2.5-3 days followed by a secondary settling tank with an HRT of 30 minutes. HRAS II was generated in a pilot plant of $50 \mathrm{~L}$ located in the same WWTP, working at the same conditions as the full-scale HRAS reactor, but with previous primary settling.

COD, TSS, VSS, TS, VS and pH were characterised according to Standard Methods (APHA, 2005). VFAs were measured by gas chromatography with flame ionization detection (FIC, HP 5890A).

\subsection{Thermal hydrolysis pilot plant}

The experiments were carried out in an automatic pilot-scale thermal system described by Sapkaite et al. (2017). The pilot plant consists on a feeding tank, a progressive cavity pump (Pmax $=12$ bar), a steam boiler, a $20 \mathrm{~L}$ total volume hydrolysis reactor $\left(\mathrm{V}_{\text {working }}=\right.$ 
$11310 \mathrm{~L})$ connected to a flash tank $(\mathrm{V}=100 \mathrm{~L})$ with outlet pipes for steam and hydrolysed

114 sludge. It is equipped with automatic valves to control the steam entrance from the boiler and the sludge exit from the reactor to the flash tank. A data acquisition and control system is used to measure pressure and temperature and to control the operation. The pump introduces $10 \mathrm{~L}$ of sludge into the reactor and then the steam valve is opened until pressure and temperature reach the set-point values. TH was carried out at $170{ }^{\circ} \mathrm{C}$ during 20 minutes, since some authors reported that non-biodegradable compounds begin to form at higher temperatures (Dwyer et al., 2008). At the end of the reaction time, the decompression valve is automatically opened and the hydrolysed sludge flows to the flash tank.

\subsection{Biomethane potential tests}

Biomethane potential (BMP) tests of the different sludges (RBF, CEPT, HRAS I and HRAS II sludges) before and after TH were carried out in an AMPTS II equipment (Bioprocess Control), following the protocol described by Holliger et al. (2016). The tests were conducted in $2 \mathrm{~L}$ bottles (1.9 L of working volume) in triplicate and with an ISR (inoculum to substrate ratio in terms of VS) of 2 . The inoculum was anaerobic flocculant biomass (15-20 g VS/L) from a mesophilic sewage sludge anaerobic digester. The reactors were dosed with macro- and micro-nutrients, and $\mathrm{pH}$ was adjusted to 7.2production. Methane production by each sludge was calculated as the difference between the average production in the bottles with substrate minus the average 
the experimental ultimate methane production, expressed in L(N)/kg VS fed, where $\mathrm{N}$ means normal conditions $\left(1 \mathrm{~atm}, 0^{\circ} \mathrm{C}\right)$. Anaerobic biodegradability $(\mathrm{AB})$ was expressed as the percentage of the initial COD of the substrate converted to methane. At the end of the test, bottles were opened and $\mathrm{pH}$ and VFAs concentration were measured to confirm that no acidification occurred.

\section{Energetic and economic assessment: case study}

\subsection{Novel WWTPs configurations and energy demand inventory}

The influence of TH on the energetic and economic balance in four different WWTPs configurations, depending on the mainstream COD recovery technology, was evaluated; three of them referring to novel scenarios based on CEPT (Figure 1A), HRAS (Figure 1B) and a combination of RBF and HRAS (Figure 1C) and one conventional activated sludge (CAS) process (Figure 1D). A 500,000 inhabitants equivalent WWTP, with a flow rate of $125 \mathrm{~L} /$ inhabitant $\cdot \mathrm{d}$ and a COD of $500 \mathrm{mg} / \mathrm{L}$ (Wan et al., 2016) was considered for all the scenarios. The energy consumption of the different units is gathered in Table 1.

\subsection{Thermal hydrolysis unit and sludge anaerobic digestion}

A combined heat and power (CHP) full integration plant was considered for all the WWTP schemes. Therefore, heat requirements of the TH unit and digester are satisfied by the exhaust gases and hot water from CHP, respectively, and electrical requirements are satisfied by the CHP electricity co-generation. For other scenarios (no heat integration, heat recovery from flash, etc.), it is known that the increase in energy production is clearly insufficient to cover the operational energy demand of the pretreatment process (Cano et al., 2015; Carrère et al., 2010). Total energy production $\left(\mathrm{E}_{\mathrm{T}}, \mathrm{kWh} / \mathrm{m}^{3}\right.$ sludge) in an anaerobic process depends on the volatile solids load (VSL, $\mathrm{kg} \mathrm{VS} / \mathrm{m}^{3}$ sludge) fed into the digester and on its biomethane production $\left(\mathrm{BMP}, \mathrm{m}^{3}(\mathrm{~N})\right.$ 
$E_{T}=V S L \cdot B M P \cdot \Delta H_{c}$

Considering a methane heat combustion $\left(\Delta H_{c}\right)$ of $11 \mathrm{kWh} / \mathrm{m}^{3}(\mathrm{~N}) \mathrm{CH}_{4}$ (Perry, 1984), and an electrical efficiency (n) of 0.35 in the co-generation motor (Mills et al., 2014), the net electrical energy produced $\left(\Delta \mathrm{E}_{\text {elec }}\right)$ expressed as the difference between the energy produced by pretreated sludge minus the energy produced by fresh sludge can be obtained by Equation 2:

$\Delta E_{\text {elec }}=V S L \cdot\left(S M P_{\text {pret }}-S M P_{\text {fresh }}\right) \cdot \Delta H_{c} \cdot \eta$

TH demands around $10 \mathrm{kWh} / \mathrm{m}^{3}$ sludge of electrical energy (Cano et al., 2015), so it results feasible when the increase in electricity generation (Eq. 2) exceeds this requirement. A maximum TS concentration of $20 \%$ was considered for the sludges, since higher values are not attainable with conventional centrifuges (Cano et al., 2015; Zhang et al., 2018), except for RBF sludge, which can be easily dewatered till $30 \%$ of TS (Paulsrud et al., 2014; Ruiken et al., 2013). Finally, Eq. 3-5 were applied to calculate total digested solids production:

$\mathrm{VS}_{\text {prod }}=0.5 \mathrm{kgCOD} / \mathrm{m}^{3} \cdot \mathrm{COD}_{\text {rec }} \cdot(\mathrm{VS} / \mathrm{COD})_{\text {sludge }}$

$\mathrm{TS}_{\text {prod }}=0.5 \mathrm{kgCOD} / \mathrm{m}^{3} \cdot \mathrm{COD}_{\text {rec }} \cdot(\mathrm{TS} / \mathrm{COD})_{\text {sludge }}$

$180 \quad \mathrm{TS}_{\text {dig }}=T S_{\text {prod }}-\mathrm{VS}_{\text {prod }} \cdot A B_{\text {sludge }}$

Where:

$\mathrm{VS}_{\text {prod: }}$ VS production in each preconcentration technology $\left(\mathrm{kg} \mathrm{VS} / \mathrm{m}^{3}\right.$ wastewater treated).

$\mathrm{TS}_{\text {prod: }}$ TS production in each preconcentration technology $\left(\mathrm{kg} \mathrm{TS} / \mathrm{m}^{3}\right.$ wastewater treated).

$\mathrm{TS}_{\text {dig: }}$ Digested total solids production $\left(\mathrm{kg} \mathrm{TS} / \mathrm{m}^{3}\right.$ wastewater treated). $\mathrm{COD}_{\text {rec: }} \mathrm{COD}$ fraction of the influent recovered in each preconcentration alternative. 
$\mathrm{VS} / \mathrm{COD}_{\text {slduge: }} \mathrm{VS}$ to COD ratio of the sludge produced in each preconcentration alternative.

$\mathrm{TS} / \mathrm{COD}_{\text {slduge: }} \mathrm{TS}$ to COD ratio of the sludge produced in each preconcentration alternative.

$\mathrm{AB}_{\text {sludge: }}$ anaerobic biodegradability, i.e. fraction of COD of sludge converted to $\mathrm{CH}_{4}$ in the BMP tests (the same value was considered for VS degradation).

\subsection{Data for economic evaluation}

Ferric chloride and electricity costs of $220 € /$ ton and $0.12 € / \mathrm{kWh}$, respectively, were considered (De Feo et al., 2008; STOWA, 2010). When TH is not included, a hygienization cost for composting of digested sludge of $80 € /$ ton TS was assumed (Management Company, 2019) In order to evaluate the possible fluctuations in electricity and sludge management costs, a sensitivity analysis was performed varying their costs in the range $0.10-0.14 € / \mathrm{kWh}$ and $60-100 € /$ ton TS, respectively. There is an important economy of scale in TH full-scale plants. Hence, to evaluate the importance of the WWTP size on the payback time for a new installation, four different plant size were considered; 100,000, 250,000, 500,000 and 1,000,000 of population equivalent WWTPs, with investment costs of $1,000,000 €, 1,250,000 €, 1,500,000 €$ and $2,000,000 €$, respectively. The estimation of the payback time for TH plants was done according to Equation 6.

Payback time $=\frac{\text { Sludge prod } \cdot \text { Manag } \cdot \operatorname{cost}+\Delta E_{\text {elec }} \cdot \text { Elec. cost }- \text { Mainteinaince }}{\text { Investment cost }}$

Where:

210 Sludge prod.: digested sludge production (ton TS/year).

211 Manag. cost: hygienization cost for composting of digested sludge (€/ton TS). $\Delta \mathrm{E}_{\text {elec: }}$ electricity generation (+) or demand (-) of the TH plant (kWh/year). 
213 Elec. cost: electricity cost (€/kWh).

214 Maintenance: maintenance cost of the TH plant (assumed as $10.000 € /$ year).

\section{4. Results and discussion}

216 4.1. COD recovery in the different alternatives

217 CEPT with the addition of $125-150 \mathrm{mg} / \mathrm{L}$ of ferric chloride was the technology leading 218 to the highest COD recovery (84\%). It removes almost completely particulate COD $219(>95 \%)$ and up to $55 \%$ of $\mathrm{COD}_{\text {sol, }}$, values in accordance with other authors (De Feo et 220 al., 2008; Wang et al., 2009). Similar COD $_{\text {tot }}$ removal was achieved in HRAS I reactor. However, it must be pointed out that around $15 \%$ of the influent $\mathrm{COD}_{\text {tot }}$ was oxidized to $\mathrm{CO}_{2}$ (calculated form the COD balance) and subsequently not recovered as sludge, in accordance with other authors (Ge et al., 2017), resulting in a final $\mathrm{COD}_{\text {tot }}$ recovery of approximately $80 \%$ RBF was the technology achieving the lowest removal efficiencies $\left(\mathrm{COD}_{\text {tot }}(35 \%)\right.$ and $\mathrm{COD}_{\text {sol }}(0 \%)$ ), which is in accordance with other reported values (Ruiken et al., 2013; Rusten et al., 2017). As the COD removal is not enough, their effluents need further treatment before a PN-anammox unit, so a HRAS reactor after RBF has been considered in this study. In this HRAS reactor, a $\mathrm{COD}_{\text {tot }}$ removal of $86 \%$ was obtained, which are equivalent to those commonly assumed in CAS reactors. However, $\mathrm{COD}_{\text {tot }}$ mineralization was much lower $(30 \%)$ than those obtained in nitrifying-denitrifying reactors, in which it can be up to 50\% (Garrido et al., 2013; Wan et al., 2016), explained by the much lower SRT (3 vs 15-20 days). Hence, the combination of RBF and HRAS reactor led to a $\mathrm{COD}_{\text {tot }}$ recovery of $70 \%$, slightly lower than in CEPT and HRAS I

\section{5 configurations.}


RBF sludge showed the highest VS/TS ratio (0.89) and the lowest COD/VS ratio (1.20)

239 (Table 2), in agreement with Paulsrud et al. (2014). This fact is explained by the high

240 percentage of cellulose in the sludge (up to 79\% of TS) (Ruiken et al., 2013). Both fresh and pretreated RBF sludge displayed similar methane potential (315 and $323 \mathrm{~L}(\mathrm{~N})$

$\mathrm{CH}_{4} / \mathrm{kg}$ VS, respectively) (Figure 2), with the highest $\mathrm{AB}(76.8 \%$ and $78.0 \%$, respectively) among the four sludges, in accordance with other values from the literature (Ghasimi et al., 2016, 2015; Paulsrud et al., 2014).

CEPT sludge displayed the highest COD/VS ratio (1.68), explained by a higher fat proportion, close to those reported by other authors for primary sludge (Carballa et al., 2007; Paulsrud et al., 2014). Moreover, it showed the lowest VS/TS ratio (0.69), characteristic from a CEPT process using metal salts, which increase the proportion of inorganic solids (De Feo et al., 2008). Contrary to RBF sludge, TH affected its methane potential (Figure 2), i.e. 300 and $340 \mathrm{~L}(\mathrm{~N}) \mathrm{CH}_{4} / \mathrm{kg}$ VS for fresh and pretreated sludge, respectively, corresponding to $\mathrm{AB}$ of $51.2 \%$ and $56.8 \%$, similar to the $\mathrm{BMP}$ obtained for conventional primary sludge from the same WWTP (303 L(N) $\mathrm{CH}_{4} / \mathrm{kg}$ VS, data not shown). This indicates that $\mathrm{Fe}^{3+}$ reduction, which is thermodynamically more favourable, did not limit the conversion of organics to methane (Romero-Güiza et al., 2016; Zhang et al., 2009). On the contrary, Kooijman et al. (2017) found that the BMP of CEPT sludges were considerably higher than those of CPS and attributed to the fact that additional small particles with a higher biodegradability are removed during CEPT, which was not seen in this study.

HRAS I characteristics (VS/TS ratio of 0.72 and COD/VS ratio of 1.71) are similar to conventional mixed sludge (MS) (Astals et al., 2012; Carballa et al., 2007), since particulate matter entering the HRAS reactor is removed through adsorption or particulate enmeshment rather than biotransformation (Jimenez et al., 2005). 
Regarding its BMP, it must be pointed that although there is extensive research focused on AD of long SRT (>10 days) sludges, the evaluation of those sludges produced at short SRT, especially below 5 days, has been limited so far (Ge et al., 2013). Fresh HRAS I sludge showed a BMP of $323 \mathrm{~L}(\mathrm{~N}) \mathrm{CH}_{4} / \mathrm{kg}$ VS (corresponding to $53.9 \%$ of $\mathrm{AB})$, which increased around $13 \%\left(363 \mathrm{~L}(\mathrm{~N}) \mathrm{CH}_{4} / \mathrm{kg} \mathrm{VS}, 62.0 \%\right.$ of $\left.\mathrm{AB}\right)$ after $\mathrm{TH}$ (Figure 2). Ge et al. (2013) reported an AB of $60 \%$ for HRAS sludges working at SRT of 2 days and found that it decreased nearly $10 \%$ with every additional day of SRT, which can explain our results (SRT of 3 days). The BMP increase after TH was in the range of other reported values for MS (5-40\%), which is very sensitive to the proportion of primary and biological sludge (Higgins et al., 2017; Kepp et al., 2000; Perez-Elvira et al., 2008).

Finally, the characteristics of HRAS II (VS/TS ratio (0.76) and COD/VS ratio (1.52)) are comparable to those of conventional waste activated sludge (WAS) (Cano et al., 2015; Mahdy et al., 2014; Perez-Elvira et al., 2008; Thorin et al., 2017). BMP of fresh and pretreated HRAS II sludge were $257(\mathrm{~N}) \mathrm{CH}_{4} / \mathrm{kg}$ VS $(47.9 \%$ of $\mathrm{AB})$ and $309 \mathrm{~L}(\mathrm{~N})$ $\mathrm{CH}_{4} / \mathrm{kg}$ VS (58.8\% of AB), respectively (Figure 2). Despite HRAS II displayed the lowest BMP among the fresh novel sludges, it resulted $20 \%$ more biodegradable than WAS ( 40\% of AB) (Garrido et al., 2013; Wan et al., 2016). However, after TH similar BMP values were achieved.

The neutral $\mathrm{pH}$ values (7.3-7.7) and the absence of VFA (<2.5 ppm acetic acid) at the end of the tests (data not shown) indicate that the performance of the tests was adequate and no acidification occurred.

\subsection{Influence of thermal hydrolysis on methane and sludge production}

In Figure 3A the expected average methane production in the four configurations for a 500,000 inhabitants WWTP, with and without TH is shown. WWTPs based on CEPT 
and on RBF+HRAS II produce the highest methane flow $\left(4,700 \mathrm{~m}^{3}(\mathrm{~N}) / \mathrm{d}\right)$, which increases to $5,300 \mathrm{~m}^{3}(\mathrm{~N}) / \mathrm{d}$ after TH. On the contrary, WWTPs based on HRAS I show a lower methane production (around 4,100 $\mathrm{m}^{3}(\mathrm{~N}) / \mathrm{d}$ ) increasing to $4,600 \mathrm{~m}^{3}(\mathrm{~N}) / \mathrm{d}$ after TH. For the conventional scenario, methane production only attained 2,900 $\mathrm{m}^{3}(\mathrm{~N}) / \mathrm{d}$, much lower than in novel configurations, explained by the lower COD recovery and the lower BMP of the sludge without TH. However, the effect of TH was much more relevant, as methane production raises up to $4,000 \mathrm{~m}^{3}(\mathrm{~N}) / \mathrm{d}$, an increase 2-fold higher than in novel scenarios.

Regarding solids production (Equations 3-6), CEPT leads to the highest digested sludge flow (14.7 tons TS/d, Figure 3B), explained by the solids increase due to the inorganic compounds precipitated. Even after TH (13.9 tons TS/d), it is higher than the obtained in other scenarios without TH. HRAS I and the combination RBF+HRAS II produce around 10.9 and 9.3 tons TS/d, respectively, achieving in both scenarios a reduction of 1.0 ton TS/d when sludge is pretreated. Digested sludge flow in conventional scenario is 11.1 tons TS/d, achieving a noticeable higher reduction in comparison with other configurations when TH is applied (2.1 tons TS/d).

\subsection{Energetic integration of thermal hydrolysis in WWTPs}

In this section, an energetic balance in the TH unit in the three different novel scenarios was performed and compared with the conventional one. The TH unit demands an electrical energy of around $10 \mathrm{kWh} / \mathrm{m}^{3}$ sludge in the feeding. Thickening the sludge and increasing the TS concentration reduces its volume and subsequently the energy consumption, so the feasibility of the TH unit is increased. For novel scenarios, the threshold sludge concentration in the TH unit to become energetically self-sufficient (Eq. 2) was between $7 \%$ and $9 \%$ (it must be noted that for RBF a concentration of $30 \%$ was considered since it is easily attainable, so the threshold sludge concentration of the 
mix RBF+HRAS sludges was 12\%), being this value around 2-fold higher than in conventional scenarios $(4 \%)$.

The impact of sludge TS concentration in the feeding to the TH unit on the energy demand of the WWTP is represented in Figure 4A. The optimised scenario consists on thickening sludges up to $20 \%$ of TS. The three novel scenarios lead to a much lower energy consumption in comparison with the conventional one when TH is not applied. However, in the conventional scenario TH has a more relevant effect since it can reduce almost $0.05 \mathrm{kWh} / \mathrm{m}^{3}$ wastewater, whereas for novel scenarios a maximum energy reduction of $0.02-0.03 \mathrm{kWh} / \mathrm{m}^{3}$ wastewater can be achieved. Even so, in any of the evaluated scenarios the WWTP energy autarky can be reached. Among them, CEPT is the one that allow to obtain the lowest energy demand regardless sludge TS concentration. However, this does not necessary mean that this technology achieves the lowest treatment costs, since other treatment costs need to be considered.

\subsection{Impact of thermal hydrolysis on operational costs}

. The influence of $\mathrm{TH}$ on these costs is displayed in Figure 4B. TH has a beneficial impact on WWTP operational costs even when sludge TS concentration is $1-2 \%$ for novel and also conventional scenarios. These minimum values are lower than those found in the previous section for the TH unit to be energetically profitable since sludge management costs are greatly reduced. Therefore, even if the TH unit becomes electricity demanding it can result economically favourable. Detailed information about the contribution of each factor (electricity, sludge management and coagulant) on WWTP operational costs without TH is shown in Section S1 in the Supporting Information.

Although the alternative based on CEPT was the one with the lowest energy requirements, it achieves the highest operational costs (Figure 4B) (mainly due to the 
addition of ferric chloride), which are very comparable with the conventional scenario (Figure 4B). WWTP based on HRAS and on the combination of RBF+HRAS resulted on 2- to 3-fold lower operational costs. The former drives to the lowest operational costs which can result even below $1 \mathrm{c} € / \mathrm{m}^{3}$ of wastewater (Figure $4 \mathrm{~B}$ ) when sludge is thickened till more than $10 \%$ of TS. Moreover, the operational costs in these novel scenarios would be very low affected by a fluctuation of the electricity cost since they present a considerably lower energy demand.

The economic impact of additional self-produced electricity and sludge disposal savings are specifically shown in Figure 5. In novel scenarios, for a TS concentration of 10\%, almost no benefit from electricity production in novel schemes is obtained, being sludge disposal savings $270,000 € /$ year for RBF+HRAS scenario, 320,000 €/year for HRAS alternative and 430,000 €/year for CEPT scenario (Figure 5). In conventional WWTPs, the economic benefits of TH due to extra self-produced electricity are much higher (110,000-145,000 €/year, Figure 5), being sludge disposal comparable to those of the HRAS scenario (320,000 €/year, Figure 5). In the optimised scenario, TH in novel configurations drives to an additional economic benefit of $35,000-58,000 € /$ year due to extra self-produced electricity. Moreover, the sensitivity analysis shows that a potential variation in electricity cost would have a negligible impact on the economic profits of TH plants. As a conclusion, it appears that the impact of TH on reducing wastewater treatment costs is mainly due to sludge disposal savings rather than other energetic factors.

\subsection{Economy of scale: influence of the WWTP size on the payback time of TH unit} Figure 6 shows the influence of sludge TS concentration on the payback times for the TH unit in the different WWTP sizes considered in this work. The comparison of the different WWTP configurations for a specific size shows that the conventional scenario 
is the one that achieves the lowest payback times, whereas the alternative based on RBF+HRAS is the one achieving the highest ones. The effect of TS concentration on the payback time is much more relevant in the 100,000 inhabitants WWTP (Figure 6A), and more specifically in the range $5-11 \%$ of TS. The minimum payback times for this WWTP size are 23 years for the scenario based on RBF+HRAS and 15-16 for the others, including the conventional alternative, what might result too high. For the 250,000 inhabitants WWTP (Figure 6B) payback times are 2-fold decreased compared to the 100,000 inhabitants WWTP, achieving minimum values of 9 years for the $\mathrm{RBF}+\mathrm{HRAS}$ alternative and around 6 for the others.

For the 500,000 and 1,000,000 inhabitants WWTPs (Figure 7C and 7D, respectively), considerably lower payback periods were determined. Sludge concentration has a much lower influence on payback time than in smaller WWTPs. Minimum values of 5 years for RBF+HRAS configuration and of 3-4 years for the other alternatives were calculated for the 500,000 inhabitants WWTP. Very similar payback periods were achieved for the 1,000,000 inhabitants WWTP, which range from 2 to 4 years, being the influence of TS concentration almost negligible. Specific information regarding the sensitivity analysis is gathered in Section S2 in the Supporting Information.

\section{Conclusions}

Sludge thermal hydrolysis approaches novel WWTPs to the energy self-sufficiency, which is not reachable in any of the analysed configurations. In novel WWTP schemes, the impact of thermal hydrolysis on the WWTP economy is mainly due to sludge disposal savings rather than other energetic factors and a minimum total solids concentration of approximately $1-2 \%$ to achieve a reduction in operational costs was found. Payback times for a new thermal hydrolysis unit are greatly dependent on the WWTP size, showing that their profitability is considerably higher in huge WWTPs. 


\section{Acknowledgements}

The authors would like to thank the EU (ID199) and AEI (PCIN2015-22) for funding, in the frame of the collaborative international Consortium Pioneer_STP financed under Water Joint Programming Initiative. The authors belong to the Galician Competitive Research Group ED431C 2017/029 and the CRETUS Strategic Partnership (ED431E 2018/01). These programmers are co-funded by FEDER (EU). Authors also want to thank Professor Fernando Fdz-Polanco for his support, providing the full-scale data.

\section{References}

APHA, 2005. Standard Methods for the Examination of Water and Wastewater, 21 st ed. American Public Health Association/American Water Works Association/Water Environment Federation, Washington DC, USA. American Public Health Association, Washington DC.

Astals, S., Venegas, C., Peces, M., Jofre, J., Lucena, F., Mata-Alvarez, J., 2012. Balancing hygienization and anaerobic digestion of raw sewage sludge. Water Res. 46, 6218-6227. doi:10.1016/j.watres.2012.07.035

Barber, W.P.F., 2016. Thermal hydrolysis for sewage treatment: A critical review. Water Res. 104, 53-71. doi:10.1016/j.watres.2016.07.069

Behera, C.R., Santoro, D., Gernaey, K. V., Sin, G., 2018. Organic carbon recovery modeling for a rotating belt filter and its impact assessment on a plant-wide scale. Chem. Eng. J. 334, 1965-1976. doi:10.1016/j.cej.2017.11.091

Bougrier, C., Albasi, C., Delgenès, J.P., Carrère, H., 2006a. Effect of ultrasonic, thermal and ozone pre-treatments on waste activated sludge solubilisation and anaerobic biodegradability. Chem. Eng. Process. Process Intensif. 45, 711-718. doi:10.1016/j.cep.2006.02.005

Bougrier, C., Delgenès, J.P., Carrère, H., 2006b. Combination of thermal treatments and anaerobic digestion to reduce sewage sludge quantity and improve biogas yield. Process Saf. Environ. Prot. 84, 280-284. doi:10.1205/psep.05162

Cano, R., Pérez-Elvira, S.I., Fdz-Polanco, F., 2015. Energy feasibility study of sludge pretreatments: A review. Appl. Energy 149, 176-185. doi:10.1016/j.apenergy.2015.03.132

Carballa, M., Omil, F., Ternes, T., Lema, J.M., 2007. Fate of pharmaceutical and personal care products (PPCPs) during anaerobic digestion of sewage sludge. Water Res. 41, 2139-2150. doi:10.1016/j.watres.2007.02.012

Carrère, H., Dumas, C., Battimelli, A., Batstone, D.J., Delgenès, J.P., Steyer, J.P., Ferrer, I., 2010. Pretreatment methods to improve sludge anaerobic degradability: A review. J. Hazard. Mater. 183, 1-15. doi:10.1016/j.jhazmat.2010.06.129

De Feo, G., De Gisi, S., Galasso, M., 2008. Definition of a practical multi-criteria procedure for selecting the best coagulant in a chemically assisted primary sedimentation process for the treatment of urban wastewater. Desalination 230, 229-238. doi:10.1016/j.desal.2007.12.003

Dwyer, J., Starrenburg, D., Tait, S., Barr, K., Batstone, D.J., Lant, P., 2008. Decreasing activated 
sludge thermal hydrolysis temperature reduces product colour, without decreasing degradability. Water Res. 42, 4699-4709. doi:10.1016/j.watres.2008.08.019

EC, 2008. Environmental, economic and social impacts of the use of sewage sludge on land Final Report Part I: Overview Report.http://ec.europa.eu/environment/archives/waste/sludge/pdf/part_i_report.pdf

EC, 2000. Working Document on Sludge. 27 April 2000-ENV.E.3/LM. 3rd draft. EC, Brussels. (Accessed $27^{\text {th }}$ March 2019). http://www.ewaonline.eu/comments.html?file=tl_files/_media/content/documents_pdf/European\%20Wate r\%20Policy/Comments/Sewage\%20Sludge/EWA_WD_sludge_en.pdf

Fdz-Polanco, F., Velazquez, R., Perez-Elvira, S.I., Casas, C., del Barrio, D., Cantero, F.J., FdzPolanco, M., Rodriguez, P., Panizo, L., Serrat, J., Rouge, P., 2008. Continuous thermal hydrolysis and energy integration in sludge anaerobic digestion plants. Water Sci. Technol. 57, 1221-1226. doi:10.2166/wst.2008.072

Garrido, J.M., Fdz-Polanco, M., Fdz-Polanco, F., 2013. Working with energy and mass balances: A conceptual framework to understand the limits of municipal wastewater treatment. Water Sci. Technol. 67, 2294-2301. doi:10.2166/wst.2013.124

Ge, H., Batstone, D.J., Keller, J., 2015. Biological phosphorus removal from abattoir wastewater at very short sludge ages mediated bynovel PAO clade Comamonadaceae. Water Res. 69, 173-182. doi:10.1016/j.watres.2014.11.026

Ge, H., Batstone, D.J., Keller, J., 2013. Operating aerobic wastewater treatment at very short sludge ages enables treatment and energy recovery through anaerobic sludge digestion. Water Res. 47, 6546-6557. doi:10.1016/j.watres.2013.08.017

Ge, H., Batstone, D.J., Mouiche, M., Hu, S., Keller, J., 2017. Nutrient removal and energy recovery from high-rate activated sludge processes - Impact of sludge age. Bioresour. Technol. 245, 1155-1161. doi:10.1016/j.biortech.2017.08.115

Ghasimi, D.S.M., Tao, Y., de Kreuk, M., Abbas, B., Zandvoort, M.H., van Lier, J.B., 2015. Digester performance and microbial community changes in thermophilic and mesophilic sequencing batch reactors fed with the fine sieved fraction of municipal sewage. Water Res. 87, 483-493. doi:10.1016/j.watres.2015.04.027

Ghasimi, D.S.M., Zandvoort, M.H., Adriaanse, M., Lier, J.B. Van, Kreuk, M. De, 2016. Comparative analysis of the digestibility of sewage fine sieved fraction and hygiene paper produced from virgin fibers and recycled fibers. Waste Manag. 53, 156-164. doi:10.1016/j.wasman.2016.04.034

Gikas, P., 2017. Towards energy positive wastewater treatment plants. J. Environ. Manage. 203, 621-629. doi:10.1016/j.jenvman.2016.05.061

Greenfield, P.F., Batstone, D.J., 2005. Anaerobic digestion: Impact of future greenhouse gases mitigation policies on methane generation and usage. Water Sci. Technol. 52, 39-47.

Gu, Y., Li, Y., Li, X., Luo, P., Wang, H., Robinson, Z.P., Wang, X., Wu, J., Li, F., 2017. The feasibility and challenges of energy self-sufficient wastewater treatment plants. Appl. Energy 204, 1463-1475. doi:10.1016/j.apenergy.2017.02.069

Higgins, M.J., Beightol, S., Mandahar, U., Suzuki, R., Xiao, S., Lu, H.W., Le, T., Mah, J., Pathak, B., DeClippeleir, H., Novak, J.T., Al-Omari, A., Murthy, S.N., 2017. Pretreatment of a primary and secondary sludge blend at different thermal hydrolysis temperatures: Impacts on anaerobic digestion, dewatering and filtrate characteristics. Water Res. 122, 557-569. 
Holliger, C., Alves, M., Andrade, D., Angelidaki, I., Astals, S., Baier, U., Bougrier, C., Buffière, P., Carballa, M., De Wilde, V., Ebertseder, F., Fernández, B., Ficara, E., Fotidis, I., Frigon, J.C., De Laclos, H.F., Ghasimi, D.S.M., Hack, G., Hartel, M., Heerenklage, J., Horvath, I.S., Jenicek, P., Koch, K., Krautwald, J., Lizasoain, J., Liu, J., Mosberger, L., Nistor, M., Oechsner, H., Oliveira, J.V., Paterson, M., Pauss, A., Pommier, S., Porqueddu, I., Raposo, F., Ribeiro, T., Pfund, F.R., Strömberg, S., Torrijos, M., Van Eekert, M., Van Lier, J., Wedwitschka, H., Wierinck, I., 2016. Towards a standardization of biomethane potential tests. Water Sci. Technol. 74, 2515-2522. doi:10.2166/wst.2016.336

Jimenez, J.A., La Motta, E.J., Parker, D.S., 2005. Kinetics of Removal of Particulate Chemical Oxygen Demand in the Activated-Sludge Process. Water Environ. Res. 77, 437-446. doi:10.2175/106143005X67340

Ju, F., Wang, Y., Lau, F.T.K., Fung, W.C., Huang, D., Xia, Y., Zhang, T., 2016. Anaerobic digestion of chemically enhanced primary treatment (CEPT) sludge and the microbial community structure. Appl. Microbiol. Biotechnol. 100, 8975-8982. doi:10.1007/s00253-016-7730-2

Kacprzak, M., Neczaj, E., Fijałkowski, K., Grobelak, A., Grosser, A., Worwag, M., Rorat, A., Brattebo, H., Almas, A., Singh, B.R., 2017. Sewage sludge disposal strategies for sustainable development. Environ. Res. 156, 39-46. doi:10.1016/j.envres.2017.03.010

Kelessidis, A., Stasinakis, A.S., 2012. Comparative study of the methods used for treatment and final disposal of sewage sludge in European countries. Waste Manag. 32, 1186-1195. doi:10.1016/j.wasman.2012.01.012

Kepp, U., Machenbach, I., Weisz, N., Solheim, O.E., 2000. Enhanced stabilisation of sewage sludge through thermal hydrolysis-three years of experience with full scale plant. Water Sci. Technol. 42, 89-96.

Kooijman, G., De Kreuk, M.K., van Lier, J.B., 2017. Influence of chemically enhanced primary treatment on anaerobic digestion and dewaterability of waste sludge. Water Sci. Technol. 76, 2017. doi:10.2166/wst.2017.314

Longo, S., d'Antoni, B.M., Bongards, M., Chaparro, A., Cronrath, A., Fatone, F., Lema, J.M., Mauricio-Iglesias, M., Soares, A., Hospido, A., 2016. Monitoring and diagnosis of energy consumption in wastewater treatment plants. A state of the art and proposals for improvement. Appl. Energy 179, 1251-1268. doi:10.1016/j.apenergy.2016.07.043

Longo, S., Frison, N., Renzi, D., Fatone, F., Hospido, A., 2017. Is SCENA a good approach for side-stream integrated treatment from an environmental and economic point of view? Water Res. 125, 478-489. doi:10.1016/j.watres.2017.09.006

Lotti, T., Kleerebezem, R., Hu, Z., Kartal, B., de Kreuk, M.K., van Erp Taalman Kip, C., Kruit, J., Hendrickx, T.L.G., van Loosdrecht, M.C.M., 2014. Pilot-scale evaluation of anammoxbased mainstream nitrogen removal from municipal wastewater. Environ. Technol. 36, 1167-77. doi:10.1080/09593330.2014.982722

Mahdy, A., Mendez, L., Ballesteros, M., González-Fernández, C., 2014. Algaculture integration in conventional wastewater treatment plants: Anaerobic digestion comparison of primary and secondary sludge with microalgae biomass. Bioresour. Technol. 184, 236-244. doi:10.1016/j.biortech.2014.09.145

Management Company, 2019. Personal communication with management company.

Mills, N., Pearce, P., Farrow, J., Thorpe, R.B., Kirkby, N.F., 2014. Environmental \& economic life cycle assessment of current $\&$ future sewage sludge to energy technologies. Waste 
Paulsrud, B., Rusten, B., Aas, B., 2014. Increasing the sludge energy potential of wastewater treatment plants by introducing fine mesh sieves for primary treatment. Water Sci. Technol. 69, 560-565. doi:10.2166/wst.2013.737

Perez-Elvira, S.I., Fernandez-Polanco, F., Fernandez-Polanco, M., Rodrriguez, P., Rouge, P., 2008. Hydrothermal multivariable approach. Full-scale feasibility study. Electron. J. Biotechnol. 11. doi:10.2225/vol11-issue4-fulltext-14

Perry, R.H., 1984. Chemical Engineers' Handbook, 6th ed. McGraw-Hill, New York.

Romero-Güiza, M.S., Vila, J., Mata-Alvarez, J., Chimenos, J.M., Astals, S., 2016. The role of additives on anaerobic digestion: A review. Renew. Sustain. Energy Rev. 58, 1486-1499. doi:10.1016/j.rser.2015.12.094

Ruiken, C.J., Breuer, G., Klaversma, E., Santiago, T., Loosdrecht, M.C.M. Van, 2013. Sieving wastewater e Cellulose recovery, economic and energy evaluation. Water Res. 47, 43-48. doi:10.1016/j.watres.2012.08.023

Rusten, B., Rathnaweera, S.S., Rismyhr, E., Sahu, A.K., Ntiako, J., 2017. Rotating belt sieves for primary treatment, chemically enhanced primary treatment and secondary solids separation. Water Sci. Technol. 75, 1-10. doi:10.2166/wst.2017.145

Salsnes, 2016. Eco-Efficient Solids Separation Benchmarking water solutions.

Sapkaite, I., Barrado, E., Fdz-Polanco, F., Pérez-Elvira, S.I., 2017. Optimization of a thermal hydrolysis process for sludge pre-treatment. J. Environ. Manage. 192, 25-30. doi:10.1016/j.jenvman.2017.01.043

Schaubroeck, T., De Clippeleir, H., Weissenbacher, N., Dewulf, J., Boeckx, P., Vlaeminck, S.E., Wett, B., 2015. Environmental sustainability of an energy self-sufficient sewage treatment plant: Improvements through DEMON and co-digestion. Water Res. 74, 166-179. doi:10.1016/j.watres.2015.02.013

Siegrist, H., Salzgeber, D., Eugster, J., Joss, A., 2008. Anammox brings WWTP closer to energy autarky due to increased biogas production and reduced aeration energy for N-removal. Water Sci. Technol. 57, 383-388. doi:10.2166/wst.2008.048

STOWA, 2010. Influent fijnzeven in RWZI's 2010-19.

Suarez, S., Lema, J.M., Omil, F., 2009. Pre-treatment of hospital wastewater by coagulationflocculation and flotation. Bioresour. Technol. 100, 2138-2146. doi:10.1016/j.biortech.2008.11.015

Thorin, E., Olsson, J., Schwede, S., Nehrenheim, E., 2017. Co-digestion of sewage sludge and microalgae - Biogas production investigations. Appl. Energy 227, 64-72. doi:10.1016/j.apenergy.2017.08.085

Vázquez-Padín, J.R., Fernández, I., Morales, N., Campos, J.L., Mosquera-Corral, A., Méndez, R., 2011. Autotrophic nitrogen removal at low temperature. Water Sci. Technol. 63, 1282-1288. doi:10.2166/wst.2011.370

Wan, J., Gu, J., Zhao, Q., Liu, Y., 2016. COD capture: A feasible option towards energy selfsufficient domestic wastewater treatment. Sci. Rep. 6, 1-9. doi:10.1038/srep25054

Wang, H., Li, F., Keller, A.A., Xu, R., 2009. Chemically enhanced primary treatment (CEPT) for removal of carbon and nutrients from municipal wastewater treatment plants: A case study 
of Shanghai. Water Sci. Technol. 60, 1803-1809. doi:10.2166/wst.2009.547

Wang, X., Andrade, N., Shekarchi, J., Fischer, S.J., Torrents, A., Ramirez, M., 2018. Full scale study of Class A biosolids produced by thermal hydrolysis pretreatment and anaerobic digestion. Waste Manag. 78, 43-50. doi:10.1016/j.wasman.2018.05.026

Zhang, J., Li, N., Dai, X., Tao, W., Jenkinson, I.R., Li, Z., 2018. Enhanced dewaterability of sludge during anaerobic digestion with thermal hydrolysis pretreatment: New insights through structure evolution. Water Res. 131, 177-185. doi:10.1016/j.watres.2017.12.042

Zhang, L., Keller, J., Yuan, Z., 2009. Inhibition of sulfate-reducing and methanogenic activities of anaerobic sewer biofilms by ferric iron dosing. Water Res. 43, 4123-4132. doi:10.1016/j.watres.2009.06.013

Zhen, G., Lu, X., Kato, H., Zhao, Y., Li, Y.Y., 2017. Overview of pretreatment strategies for enhancing sewage sludge disintegration and subsequent anaerobic digestion: Current advances, full-scale application and future perspectives. Renew. Sustain. Energy Rev. 69, 559-577. doi:10.1016/j.rser.2016.11.187

\section{Web sites}

http://appsso.eurostat.ec.europa.eu/nui/show.do?dataset=env_ww_spd\&lang=en (last access 29.10.2018). 
575 Table 1. Data considered for the WWTP energetic evaluation.

576 Table 2. Novel sludges physico-chemical characterization. RBF: rotating belt filters

577 sludge, CEPT: chemically enhanced primary treatment sludge, HRAS: high-rate

578 activated sludge. 


\section{Technology}

Wastewater pumping

Rotating belt filters

Chemically enhanced primary treatment 0.03 (Longo et al., 2017)

High-rate activated sludge reactor

Partial nitritation-anammox reactor

Conventional primary treatment

Activated sludge reactor
0.03 (Longo et al., 2016)

0.04 (Salsnes, 2016)

$0.05 *$ (Ge et al., 2015)

$0.25 * *$ (Schaubroeck et al., 2015)

0.03 (Greenfield and Batstone, 2005)

$0.45^{* * *}$ (Gikas, 2017; Siegrist et al., 2008) $* * *$ calculated from the value of $0.37 \mathrm{kWh} / \mathrm{m} 3$ which was increased $20 \%$ to consider the organic load increase due to sludge supernatant recycling. 


\begin{tabular}{lcccc}
\hline & CEPT & HRAS I & RBF & HRAS II \\
\hline TS $(\mathrm{g} / \mathrm{kg})$ & $34.2 \pm 0.1$ & $59.2 \pm 0.1$ & $57.7 \pm 2.4$ & $44.3 \pm 0.3$ \\
$\mathrm{VS}(\mathrm{g} / \mathrm{kg})$ & $23.4 \pm 0.1$ & $42.7 \pm 0.2$ & $51.6 \pm 2.4$ & $33.6 \pm 0.2$ \\
$\mathrm{COD}_{\text {tot }}(\mathrm{g} / \mathrm{kg})$ & $39.3 \pm 4.5$ & $73.0 \pm 2.5$ & $61.9 \pm 2.0$ & $51.0 \pm 0.6$ \\
$\mathrm{COD}_{\text {sol }}(\mathrm{g} \mathrm{kg})$ & $1.02 \pm 0.01$ & $2.06 \pm 0.05$ & $1.64 \pm 0.02$ & $0.65 \pm 0.01$ \\
$\mathrm{VS} / \mathrm{TS}$ & $0.69 \pm 0.1$ & $0.72 \pm 0.04$ & $0.89 \pm 0.08$ & $0.76 \pm 0.01$ \\
$\mathrm{COD} / \mathrm{VS}$ & $1.68 \pm 0.19$ & $1.71 \pm 0.07$ & $1.20 \pm 0.06$ & $1.52 \pm 0.03$ \\
\hline
\end{tabular}




\section{Figures captions}

586 Fig. 1. Wastewater treatment plant configurations studied in this work based on: A)

587 chemically enhanced primary treatment; B) High-rate activated sludge; C) Rotating belt

588 filter + high-rate activated sludge; D) Primary settling + conventional activated sludge.

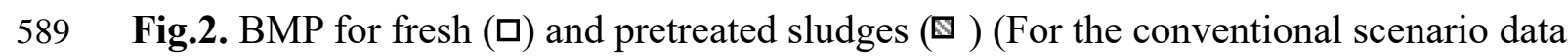
590 was considered from Perez-Elvira et al. (2008).

591 Fig. 3. A) Methane production in the different WWTP configurations (ㅁ) and additional

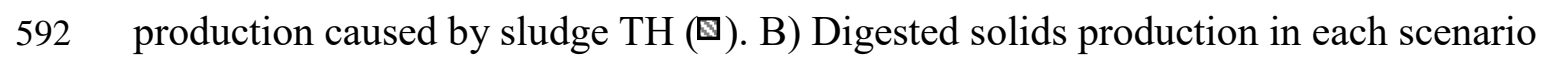
593 with (ㅁ) and without () TH.

594 Fig. 4. Influence of sludge TS concentration in the feeding to the TH unit on A) the 595 WWTP energy consumption and B) on the WWTP operational costs: CEPT ( $\triangle$ ), HRAS 596

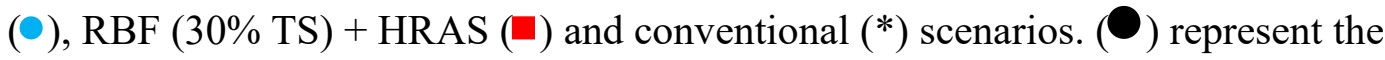
WWTP energy consumption when sludge is not pretreated before AD. Error bars represent the impact of the potential fluctuations of electricity cost.

Fig. 5. Economic benefit of sludge TH due to electricity generation (\$) and sludge 600 disposal savings ( $(\square) .10 \%$ and $20 \%$ refer to sludge TS concentration. Continuous bar errors represent the impact of the potential fluctuations of electricity cost between 0.10 and $0.14 € / \mathrm{kWh}$ and discontinuous bar errors of sludge management cost between 60 and $100 € /$ ton TS.

604

Fig. 6. Influence of sludge concentration on the payback time for a TH plant in CEPT treatment plant for A) 100,000 B) 250,000 C)500,000 and D) 1,000,000 inhabitants 607 equivalents. 


\section{Figure 1}

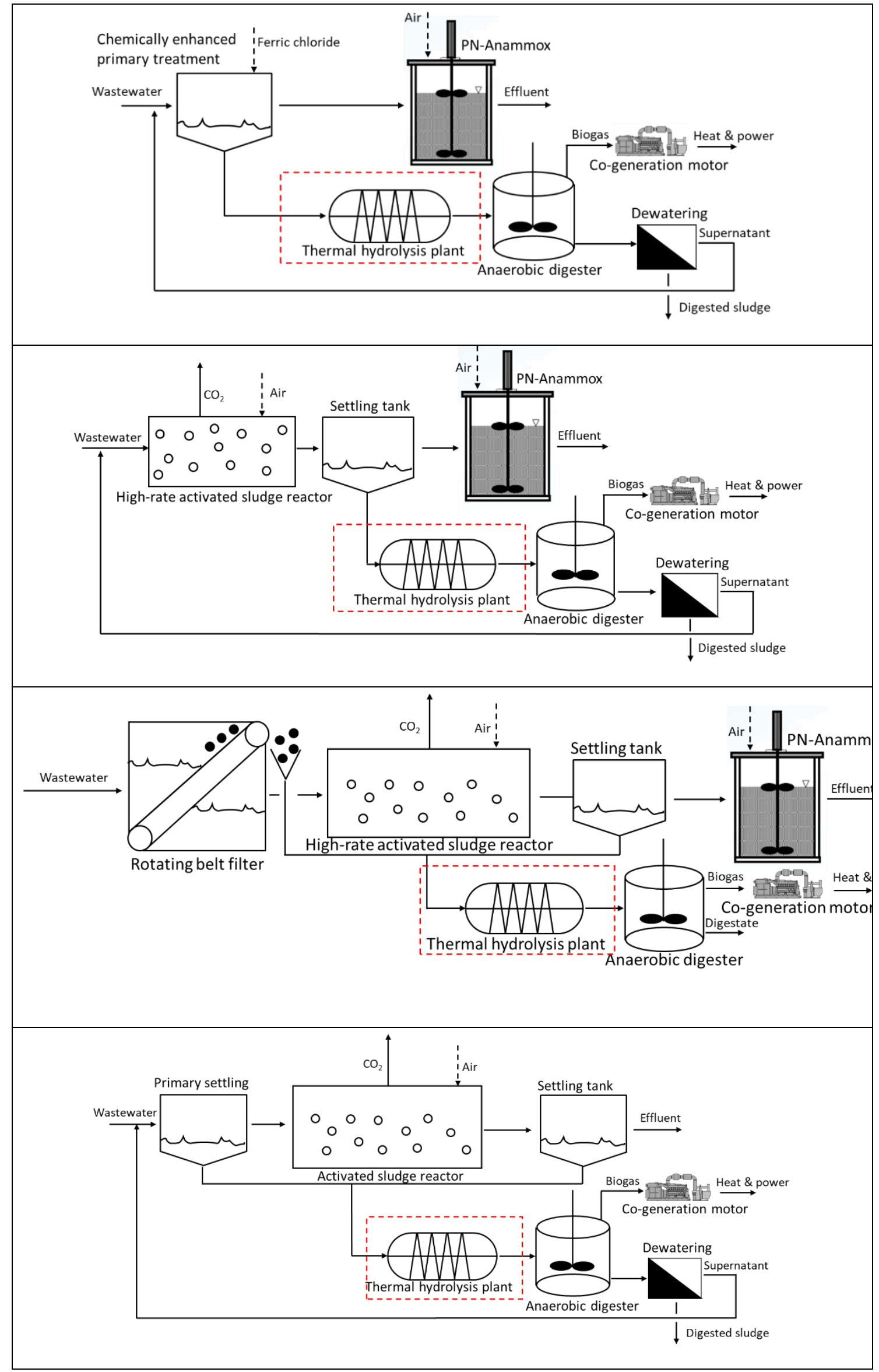

A

B 
Figure 2

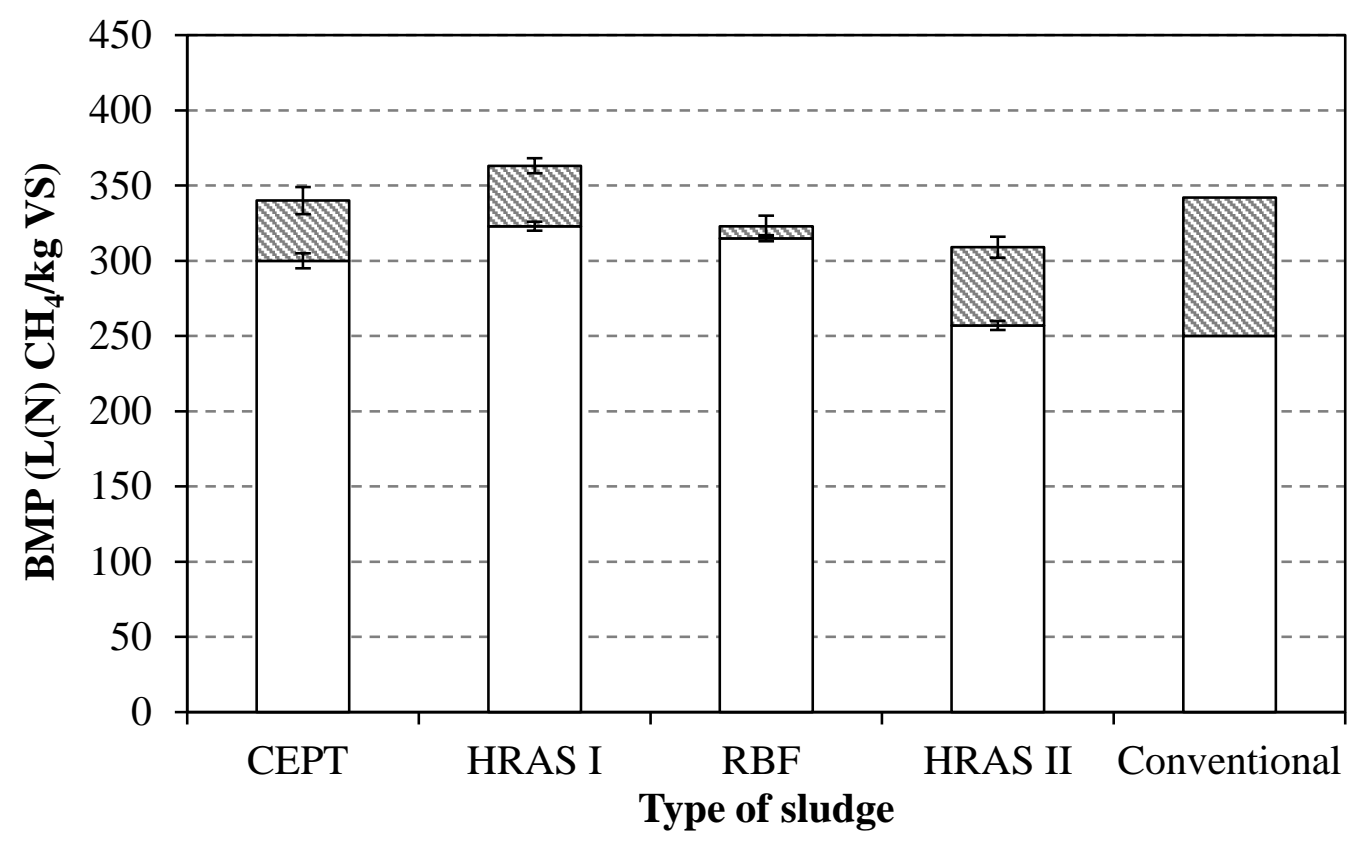

608 
Figure 3

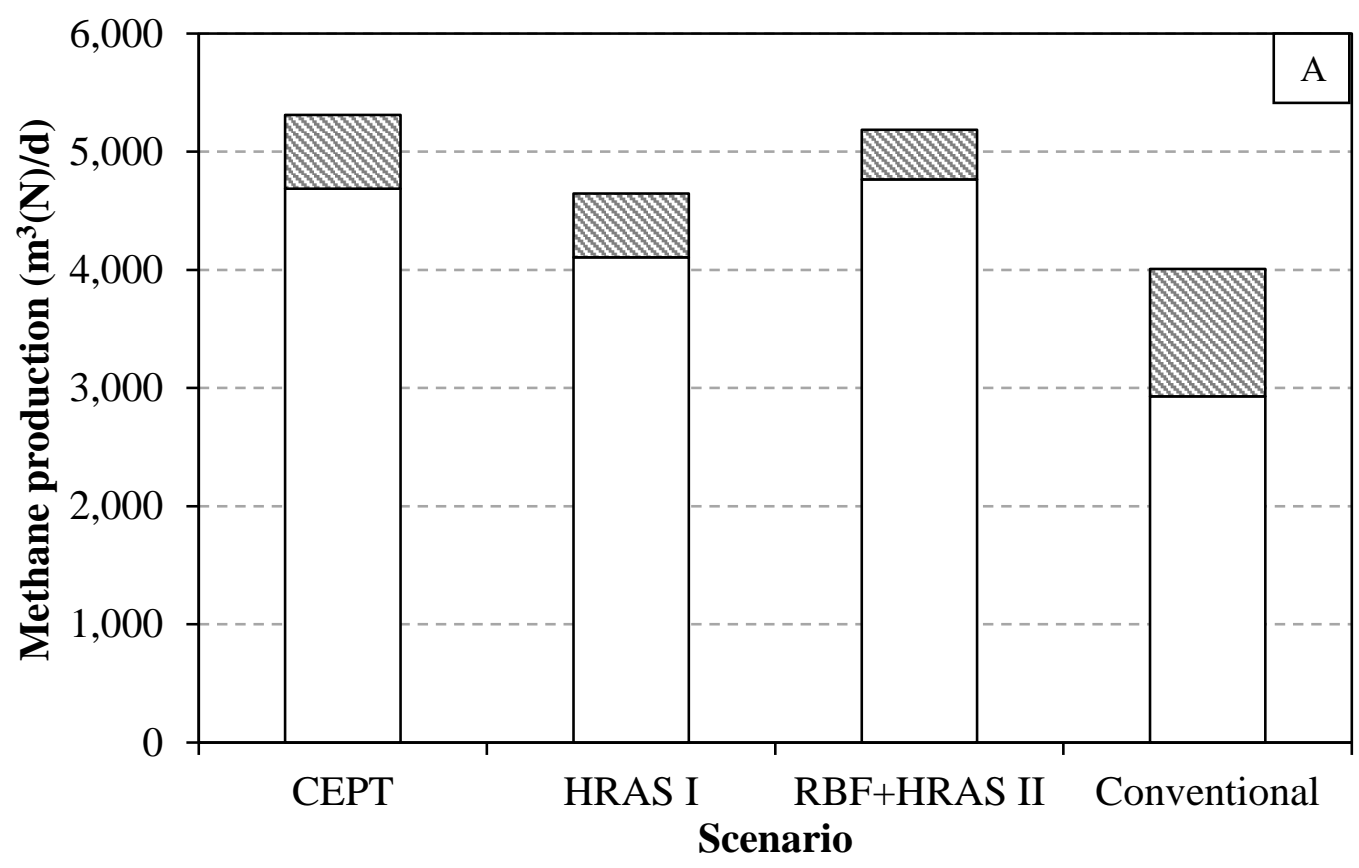

610

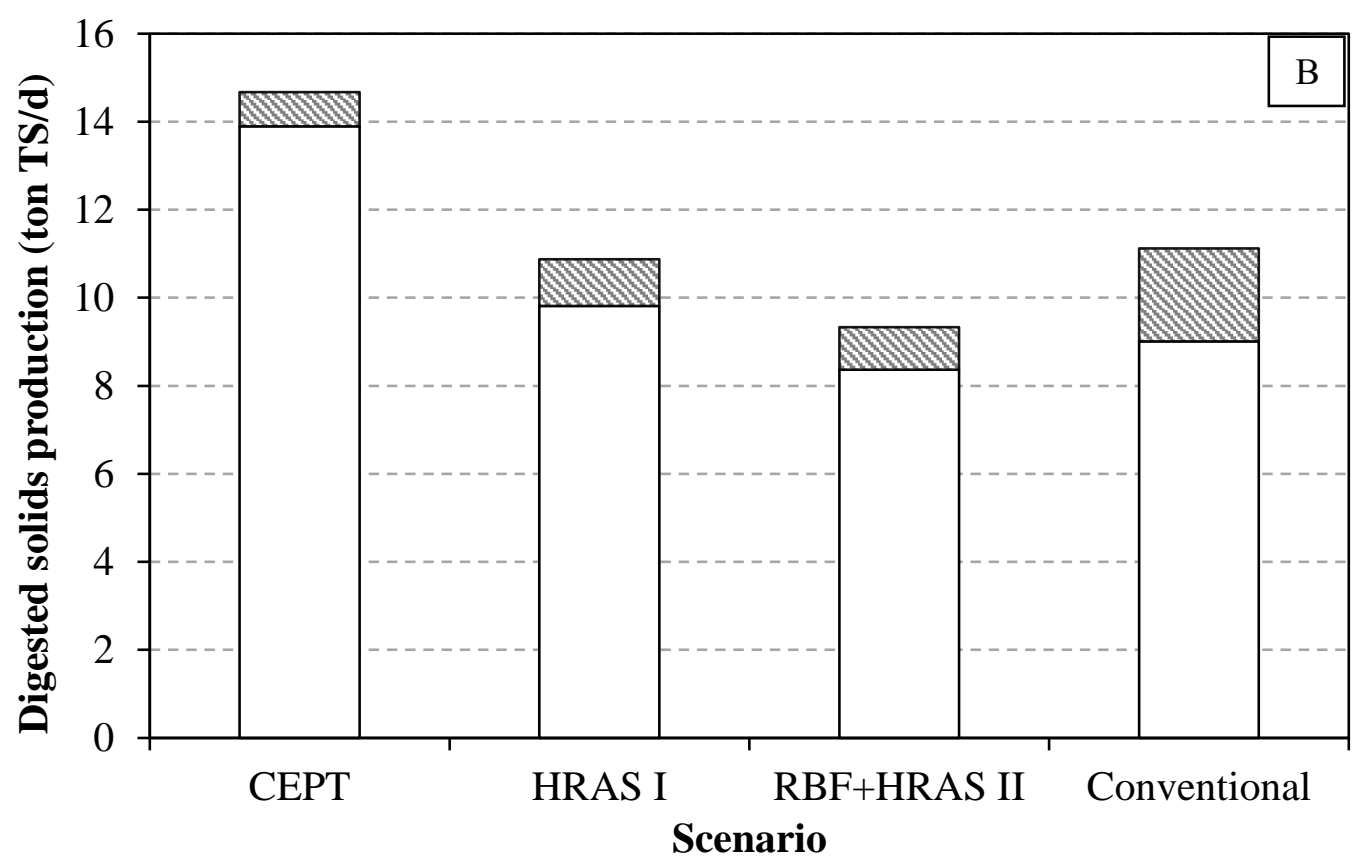


613

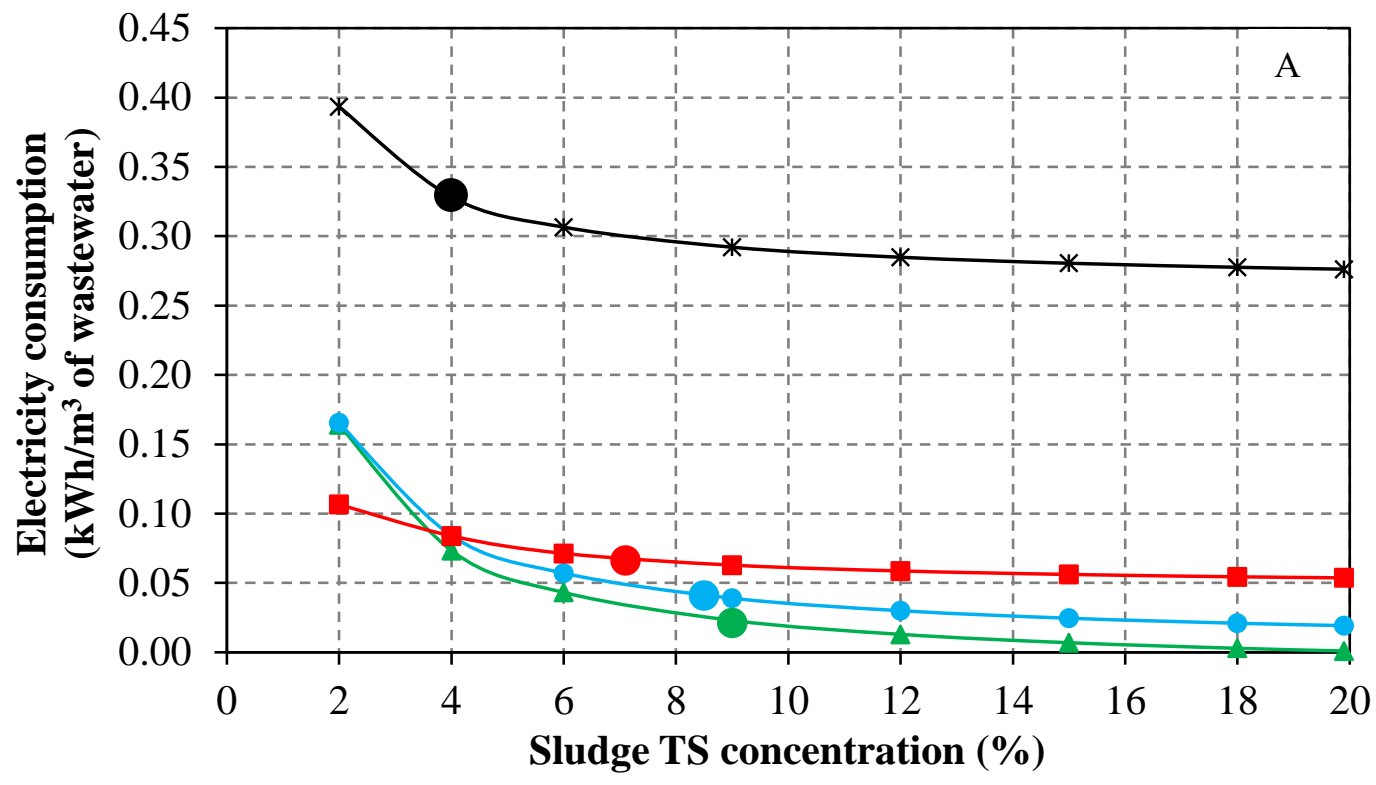

614 Sludge TS concentration (\%)

615

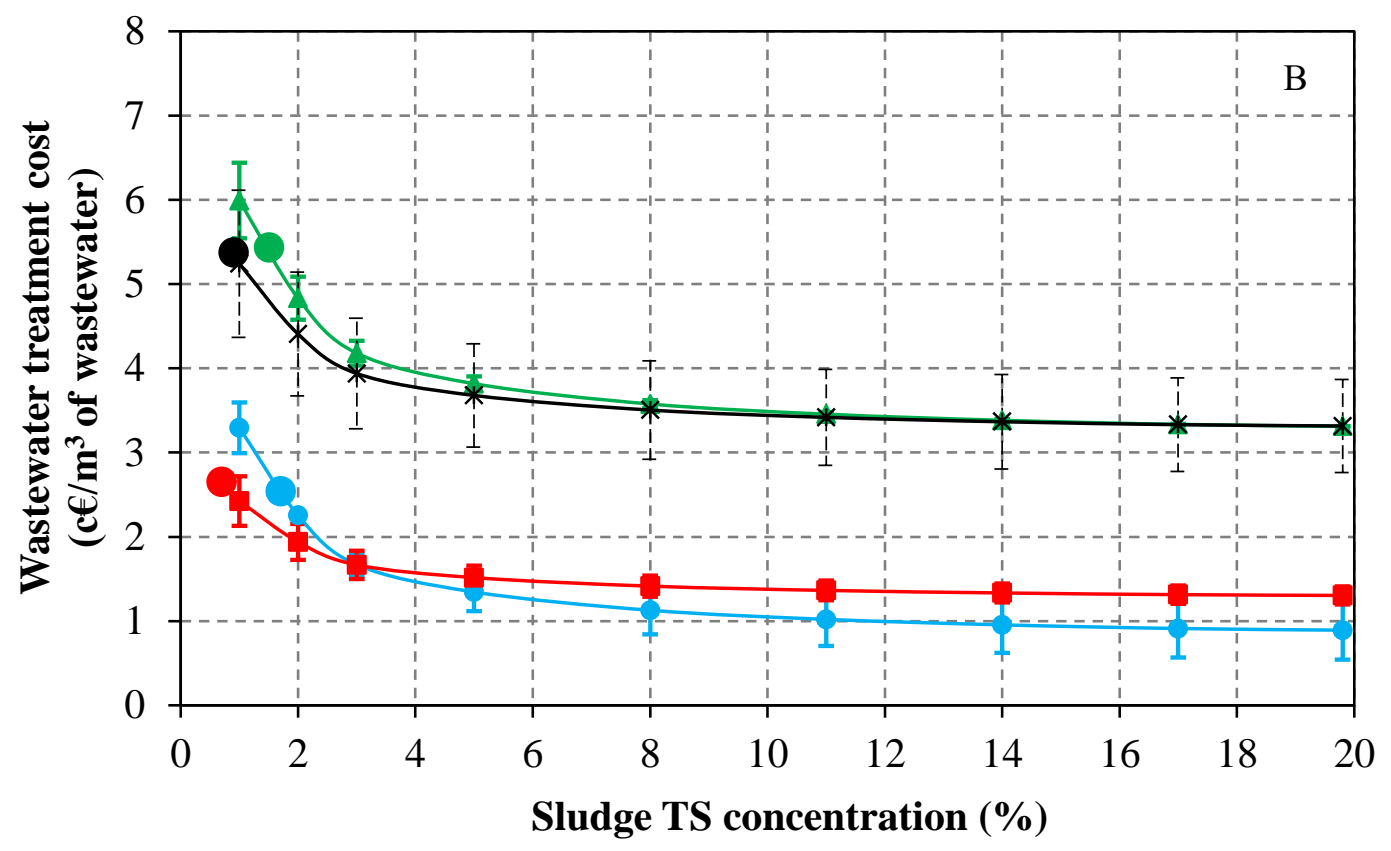

616 


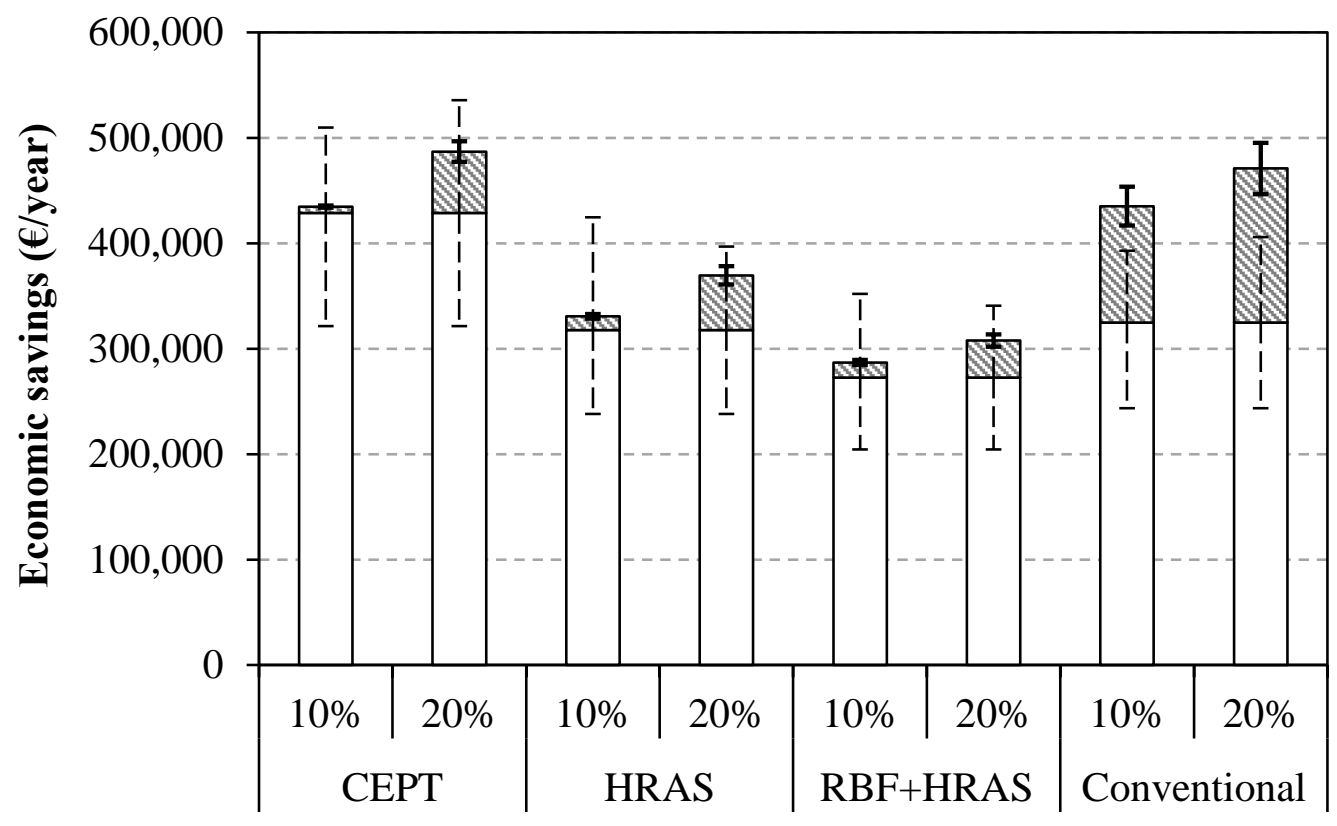



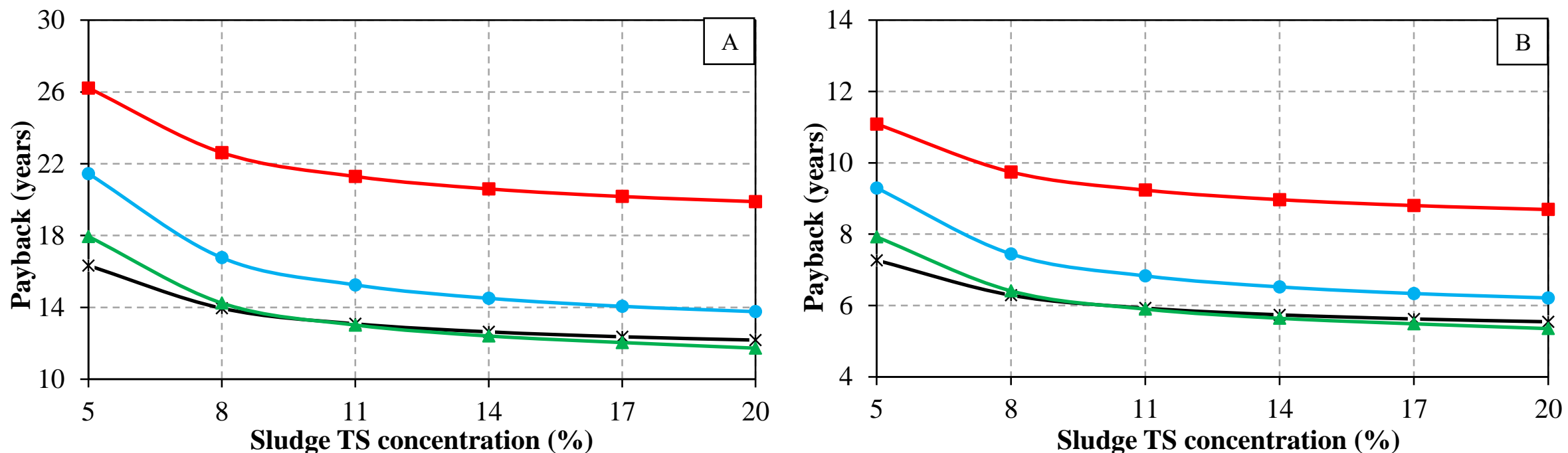

620
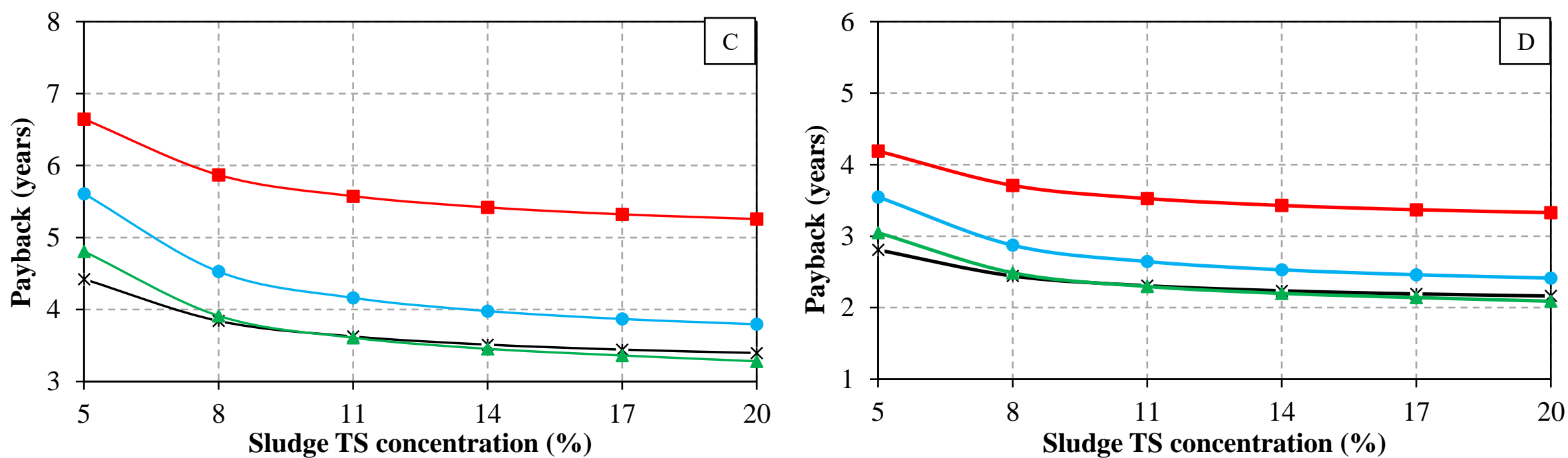